\title{
The effect of bacterial preparations on the buckwheat yield
}

\author{
Fanusa Kadyrova ${ }^{1, *}$, Lilia Klimova $^{1}$, Daria Stepankova ${ }^{1}$, Gulnaz $_{\text {Shaidullina }}{ }^{1}$, and Luiza Kadyrova $^{2}$ \\ ${ }^{1}$ Kazan State Agrarian University, Kazan 420015, Russia \\ ${ }^{2}$ Kazan (Volga) Federal University, Kazan 420008, Russia
}

\begin{abstract}
Modern crop cultivation technologies use biological products with adaptogenic and biofungicidal properties. The article studies the influence of Streptomyces sp on the growth, development, and formation of buckwheat crops. The treatment of seeds with biological products reduces field germination; however, their environmental sustainability increases. The maximum grain yield of $249.7 \mathrm{~g} / \mathrm{m}^{2}$ was obtained when applying actinomycetes in the amount of 2.01 per ton of seeds. The ability of the biological product to preserve the activity of nodes and shoots increased the number of inflorescences. The dynamics of biosynthesis and the fractional composition of chlorophyll in the leaves were studied. The biosynthesis of pigments was the most intensive during during seed treatment with Streptomyces sp in the amount of 1.0 to $1.5 \mathrm{l} / \mathrm{t}$ of seeds. The relative amount of chlorophyll "a" to chlorophyll " $\mathrm{b}$ " during the intensive development and mass flowering was relatively stable $(2.5 \ldots 2.7)$. In the phase of fruit formation, in the control plants and plants treated with Rizoplan and actinomycetes $(0.51 / \mathrm{t})$, the proportion of chlorophyll $b$ increased. In variants with a lower proportion of chlorophyll "b", the seed productivity of plants was higher.
\end{abstract}

\section{Introduction}

Environmentally friendly plant resources are widely used in the agriculture. Numerous publications provide data on the ecological and physiological role of bacterial preparations that inhabit the rhizosphere and internal tissues of plants. In particular, a positive effect on plant development and grain yield growth has been identified. Their ability to suppress pathogenic microorganisms, contributes to the neutralization of toxins in the soil and the plant, and enhances the digestibility of phosphorus and nitrogen. Associative bacteria can synthesize a number of natural products that are used by the plant itself $[1,2]$. Strains of endophytic bacteria reduce the influence of biotic and abiotic factors due to the positive biochemical and physiological effects of the latter on plants [3] Therefore, using the beneficial potential of herbal preparations is an effective resource in increasing the size and quality of the crop, as well as optimizing ecological conditions of the habitat of plants.

The application of microbiologically active preparations for buckwheat is being developed, the development of plants and the yield is subject to the significant influence of climatic stresses. They are especially critical in the zone of the Middle Volga region, when an unfavorable combination of hydrothermal vegetation conditions is observed in the most critical phases of the formation of the plants' productive potential. Spring drought or the return of cold weather in the early stages of development determines the growth processes of both the root system and terrestrial vegetative organs, reduces the number of reproductive organs. Frequently repeated soilatmospheric droughts against the background of high temperatures in the middle of the plant vegetation, during flowering and fruit formation, reduce the flight activity of bees and cause the death of a significant part of the formed ovary.

Researchers identified an increase in the agrochemical responsiveness of buckwheat plants during seed treatment with rhizoagrin and flavobacterin [4]. Their metabolic products can inhibit the development of pathogenic microflora, stimulate seed germination and increase their germination [5].

A study by Chinese scientists showed the influence of endophytic fungi from Tatar buckwheat (F.tataricum) on the growth of root hairs of the host and the production of functional metabolites. The authors say that the use of specific fungal pathogens can be an effective strategy to improve the nutritional regime and functional qualities of seedlings of Tatar buckwheat [6].

In the studies conducted on buckwheat (F.esculentum), the use of bacterial fertilizers increased the length of plants, nodes, length, width and the number of leaves in general) [7].

The aim of our research was to study the effect of seed treatment and evaluate the effectiveness of using the Streptomyces sp strain on the growth and development of buckwheat plants.

The gram-positive bacteria influence the soil and plants characterized by a complex secondary metabolism. It is known that they synthesize a large number of antibiotics that can suppress the phytopathogenic microflora. In addition, their

Corresponding author: fanusa51@ rambler.ru 
metabolites can have a growth-promoting and adaptogenic effect on plants under the influence of stressful conditions, thereby reducing the negative effects of the latter.

\section{Material and methods}

The experiment was conducted on the experimental site of the agronomical faculty of Kazan State Agrarian University, on gray forest soils with a humus content of $3.2 \%$, with an increased phosphorus content (145 mg per $100 \mathrm{~g}$ of soil) and an average potassium content (110 mg per $100 \mathrm{~g}$ of soil) with a pH of 5.3. A suspension of microorganisms Streptomyces sp was given by the Center for Agroecological Research of Kazan State Agrarian University.

Small plot experiments were performed on plots with an area of $5 \mathrm{~m}^{2}$. The technology of tillage and sowing is generally accepted for the Republic of Tatarstan. The seeding rate was 3.0 million pcs. seed per hectare. The Batyr variety used in the Middle Volga region of the Russian Federation was chosen.

The object of study was the Batyr variety, admitted to cultivation in the Middle Volga region of the Russian Federation. The variety is mid-season, has a high potential for seed productivity in comparison with other varieties cultivated in the Republic of Tatarstan, blooms evenly and actively, is bee pollinated. However, in years with the manifestation of extreme vegetation conditions, especially during the formation of generative organs, this variety significantly reduces the plant productivity coefficient due to disturbances in the process of gametogenesis and embryogenesis [8].

The experimental strain of Streptomyces sp. was compared with the control option and the option involving the treatment with Rizoplan biofungicide, chemical protectant "Armor 3" (AI tebuconazole, thiabendazole, imazalil). It is known that Rizoplan can suppress the development of phytopathogens, has a growth-activating and antidepressant effect. It has been tested on a wide range of cultures.

The study options were four standards for making suspension Streptomyces sp: $0.5 ; 1.0 ; 1.5 ; 2.0$ 1/ha with a flow rate of $200 \mathrm{l} / \mathrm{ha}$. The control preparations were used according to the recommended norms.

The hydrothermal conditions of the first half of buckwheat vegetation were arid. The rainfall deficit amounted to $60 \%$ of the normin May, less than $50 \%$ of the norm in June. For this reason, there was a slight lag in growth and branching compared to the favorable years. During the period of mass growing, the average daily temperature exceeded the long-term norm by $2.5^{\circ} \mathrm{C}$. Precipitation was only $37 \%$ of the norm. Thus, in the most critical periods of crop formation, buckwheat plants suffered from a deficit of precipitation.

The following analyzes were carried out: phenological dates of the plant development phases, field germination and ecological stability of plants, plant structure and yield of leaf surface measurements in dynamics, quantity and qualitative composition of chlorophyll, taking into account the yield of experimental options, statistical processing of experimental data.

The study of the dynamics of biomass accumulation, the leaf surface area, biometric parameters of plants, and seed productivity of plants were evaluated according to the generally accepted methods [8].

\section{Results and discussion}

The maximum field germination (99\%) was obtained when applying 1 liter per hectare (Table 1). A close value (94\%) was obtained for the control option. For other options, this indicator ranged from 70 to $80 \%$

Table 1. Field germination and environmental sustainability of buckwheat plants during seed treatment with chemical and biological preparations

\begin{tabular}{|c|c|c|c|c|}
\hline Option & $\begin{array}{c}\text { number of } \\
\text { plants in } \\
\text { seedlings }\end{array}$ & $\begin{array}{c}\text { germination, } \\
\%\end{array}$ & $\begin{array}{c}\text { number of } \\
\text { plants before } \\
\text { harvesting }\end{array}$ & $\begin{array}{c}\text { resistance, } \\
\%\end{array}$ \\
\hline The control & 284 & 94 & 207 & 73 \\
\hline Rizoplan & 220 & 73 & 161 & 73 \\
\hline $\begin{array}{c}\text { Chemical } \\
\text { disinfectant }\end{array}$ & 228 & 76 & 200 & 88 \\
\hline $\begin{array}{c}\text { Streptomyce } \\
\text { s sp., 0.5 1/t }\end{array}$ & 240 & 85 & 166 & 69 \\
\hline $1.01 / \mathrm{t}$ & 297 & 99 & 217 & 73 \\
\hline $1.5 \mathrm{l} / \mathrm{t}$ & 223 & 74 & 197 & 88 \\
\hline $2.0 \mathrm{l} / \mathrm{t}$ & 233 & 70 & 188 & 87 \\
\hline
\end{tabular}

The ecological resistance of plants to vegetation conditions, expressed as the preservation of plants for harvesting, was maximum ( $88 \%)$ in the variants with seed treatment with the strain in the amount of 1.5 and 2.0 liters per ton of seeds. In the cases where the field germination of seeds was higher, the plants' conservation for harvesting decreased to $69 \ldots 73 \%$ due to more stringent competitive relations.

During the period of mass flowering and at the beginning of fruit formation, on the options with seed treatment by the studied strain, a more intensive growth of plants was noted in length, combined with an increase in the mass of leaf-stem mass, the mass of the reproductive organs and leaf surface (Table 2).

Table 2. The effect of seed treatment on the production potential of plants of the buckwheat Batyr variety

\begin{tabular}{|c|c|c|c|c|}
\hline Option & $\begin{array}{c}\text { Root } \\
\text { mass, } \mathrm{g}\end{array}$ & $\begin{array}{c}\text { Generative } \\
\text { part mass, } \mathrm{g}\end{array}$ & $\begin{array}{c}\text { Mass of } \\
\text { the aerial } \\
\text { part of the } \\
\text { plant, } \mathrm{g}\end{array}$ & $\begin{array}{c}\text { The area of } \\
\text { leaves on } \\
\text { the plant, } \\
\mathrm{m}^{2}\end{array}$ \\
\hline Control & 0.5 & 1.6 & 6.4 & 0.06 \\
\hline Rizoplan & 2.6 & 10.6 & 30.0 & 0.25 \\
\hline $\begin{array}{c}\text { Streptomyces } \\
\text { sp: }\end{array}$ & & 12.6 & 66.3 & 0.64 \\
\hline $0.5 \mathrm{l} / \mathrm{t}$ seed & 4.9 & 6.9 & 28.2 & 0.23 \\
\hline $1.0 \mathrm{l} / \mathrm{t}$ seed & 1.9 & 5.2 & 24.7 & 0.25 \\
\hline $1.5 \mathrm{l} / \mathrm{t}$ seed & 1.8 & 6.2 & 22.6 & 0.19 \\
\hline $2.0 \mathrm{l} / \mathrm{t}$ seed & 1.7 & & & \\
\hline
\end{tabular}

Seed treatment with Streptomyces $s p$ contributed to an increase in the biometric parameters of plants (Table 3 ). 
Table 3. Biometric parameters of buckwheat during seed treatment

\begin{tabular}{|c|c|c|c|c|c|c|c|}
\hline \multirow{3}{*}{ Indicators } & \multicolumn{7}{|c|}{ Seed Processing Options } \\
\hline & \multirow{2}{*}{$\begin{array}{l}\text { The } \\
\text { control }\end{array}$} & \multirow{2}{*}{ Rizoplan } & \multirow{2}{*}{$\begin{array}{l}\text { Chemical } \\
\text { disinfectant }\end{array}$} & \multicolumn{4}{|c|}{ Suspension Streptomyces sp., l/t seed } \\
\hline & & & & 0.5 & 1.0 & 1.5 & 2.0 \\
\hline Plant height, $\mathrm{cm}$ & $63.6 \pm 3.7$ & $73.3 \pm 3.6$ & $76.5 \pm 5.9$ & $90.2 \pm 5.0$ & $80.9 \pm 4.5$ & $6.5 \pm 3.0$ & $78.4 \pm 4.9$ \\
\hline number of nodes & 6.9 & 8.4 & 8.3 & 7.5 & 9.3 & 7.5 & 9.3 \\
\hline number of shoots of the first order & 2.7 & 2.3 & 1.7 & 2,2 & 2.5 & 2.1 & 2.8 \\
\hline Leaf area, $\mathrm{m}^{2} /$ plant & 0.06 & 0.25 & 0.21 & 0.64 & 0.23 & 0.25 & 0.19 \\
\hline number of inflorescences per plant & 8.6 & 8.8 & 8.4 & 9.9 & 11.7 & 8.2 & 13.3 \\
\hline number of grains per plant & 26.5 & 31.2 & 19.6 & 31.5 & 31.8 & 23.4 & 41.4 \\
\hline
\end{tabular}

Activation of plant growth is observed in variants with a low rate of suspension $(0.5$ and $1.01 / \mathrm{t})$. Bacterial treatment with Streptomyces sp. increased the number of nodes, productive shoots of the first order, inflorescences, fruits. The value of these signs increases as the norm increases from 0.5 to $2.01 / \mathrm{t}$. When treating seeds with Rizoplan and chemical preparations, plant growth processes were activated, but the number of shoots and inflorescences significantly decreased.

Plant productivity is determined by the quantity and efficiency of photosynthetic pigments, which are responsible for the absorption and conversion of solar energy into the energy of chemical compounds. The biosynthesis of photosynthetic pigments is significantly affected by environmental conditions, including the climatic conditions of the growing season and agrotechnical methods [9]. We associated the intensity of production processes with the amount of chlorophyll in the leaves. The data on the dynamics of the chlorophyll biosynthesis "a" and "b" in the leaves of buckwheat are presented in Table 4.

Table 4. The effect of seed treatment with Streptomyces sp. on the dynamics of chlorophyll biosynthesis "a" and "b" in the leaves of buckwheat plants

\begin{tabular}{|c|c|c|c|c|c|c|}
\hline \multirow[t]{2}{*}{ option } & \multicolumn{2}{|c|}{$\begin{array}{c}\text { The amount of chlorophyll "a" } \\
\text { mg/g per wet weight }\end{array}$} & \multicolumn{2}{|c|}{$\begin{array}{c}\text { The amount of chlorophyll " } b " \text {, } \\
\text { mg/g per wet weight }\end{array}$} & \multicolumn{2}{|c|}{$\begin{array}{l}\text { The total amount of chlorophyll, } \\
\mathrm{mg} / \mathrm{g} \text { per wet weight }\end{array}$} \\
\hline & bloom & fruit formation & bloom & fruit formation & bloom & fruit formation \\
\hline control & $1.43 \pm 0.04$ & $0.45 \pm 0.09$ & $0.56 \pm 0.01$ & $0.38 \pm 0.07$ & 1.99 & 0.83 \\
\hline Rizoplan & $1.42 \pm 0.14$ & $1.20 \pm 0.06$ & $0.55 \pm 0.06$ & $0.87 \pm 0.04$ & 1.97 & 2.07 \\
\hline Chemical preparation & $1.24 \pm 0.12$ & $1.24 \pm 0.39$ & $0.47 \pm 0.02$ & $0.46 \pm 0.20$ & 1.71 & 1.70 \\
\hline $\begin{array}{l}\text { Streptomyces sp: } \\
0.51 / \mathrm{t} \text { seed }\end{array}$ & $1.18 \pm 0.05$ & $0.90 \pm 0.04$ & $0.44 \pm 0.02$ & $0.73 \pm 0.04$ & 1.61 & 1.63 \\
\hline $1.0 \mathrm{l} / \mathrm{t}$ seed & $1.55 \pm 0.13$ & $0.86 \pm 0.06$ & $0.59 \pm 0.05$ & $0.34 \pm 0.03$ & 2.14 & 1.20 \\
\hline $1.51 / \mathrm{t}$ seed & $1.68 \pm 0.20$ & $0.95 \pm 0.33$ & $0.68 \pm 0.10$ & $0.34 \pm 0.12$ & 2.36 & 1.29 \\
\hline $2.0 \mathrm{l} / \mathrm{t} \mathrm{seed}$ & $1.45 \pm 0.25$ & $0.97 \pm 0.11$ & $0.55 \pm 0.10$ & $0.37 \pm 0.04$ & 2.00 & 1.34 \\
\hline
\end{tabular}

During the period of mass flowering, the biosynthesis of pigments in the leaves of the control and experimental variants was more intensive than during the period of fruit formation. This can be explained by the accelerated rate of transition of plants to a new life cycle, when synthetic processes are replaced by the processes of attraction of plastic elements from the leaves to the fruits. The total amount of chlorophyll decreased by $58 \%$, in the variants treated with the Streptomyces sp strain - by $32 \ldots 45 \%$. When treating with Rizoplan and chemical preparations, this dynamics was not observed.

The biosynthesis of pigments during flowering and intensive growth and development when treating seeds with Streptomyces $\mathrm{sp}$ in the amount of 1 to $1.5 \mathrm{1} / \mathrm{t}$ of seeds was intensive.

Table 5 presents data on the relative amount of chlorophyll "a" to chlorophyll "b" during mass flowering and fruit formation.

During the mass flowering, this ratio was relatively stable. The amount of chlorophyll "a" exceeded the amount of chlorophyll "b" by 2.5...2.7 times.

In the phase of mass fruit formation, the proportion of chlorophyll "b" increased.
Table 5. The ratio of the amount of chlorophyll "a" to chlorophyll "b" during mass flowering and fruit formation

\begin{tabular}{|l|l|l|}
\hline \multirow{2}{*}{ option } & \multicolumn{2}{|c|}{ Quantity ratio $\langle\mathrm{a} » /\langle\mathrm{b} »\rangle$} \\
\cline { 2 - 3 } & bloom & fruit formation \\
\hline Control & 2.56 & 1.20 \\
\hline Rizoplan & 2.57 & 1.38 \\
\hline Chemical preparation & 2.67 & 2.72 \\
\hline $\begin{array}{c}\text { Streptomyces } s p: \\
0.5 \mathrm{l} / \mathrm{t} \text { seed }\end{array}$ & 2.71 & 1.24 \\
\hline $1.0 \mathrm{l} / \mathrm{t}$ seed & 2.61 & 2.55 \\
\hline $1.5 \mathrm{l} / \mathrm{t}$ seed & 2.47 & 2.64 \\
\hline $2.0 \mathrm{l} / \mathrm{t}$ seed & 2.62 & 2.72 \\
\hline
\end{tabular}

In the modern literature on plant physiology, the role of chlorophyll in the regulation of ontogenesis phases is discussed along with the photosynthetic properties of pigments. Strengthening the synthesis of chlorophyll "b" in the transgenic lines of Arabidopsis thaliana slowed down the rate of plant aging, delaying the processes of transformation of vegetative meristems and the transition of plants to subsequent phases of [10] ontogenesis.

Buckwheat is prone to unproductive growth $[11,12]$. In the regions with a short favorable period of 
vegetation, any delay in the process of fruit formation reduces its productivity [13]. Variants with a reduced proportion of chlorophyll " $b$ " accelerated the rate of formation of the reproductive system of plants, thereby increasing their seed productivity.

Table 6 presents the data on total biological productivity and productivity of experimental plots.

According to the data, the total biological productivity of plots treated with biological preparations was inferior to the control variant and the variant involving treatment with chemical preparations. To a large extent, this is due to the smaller number of plants per square meter (see Table 1).

Table 6. The effect of seed treatment with biological and chemical compounds on the buckwheat biomass and yield

\begin{tabular}{|c|c|c|c|}
\hline Options & $\begin{array}{c}\text { Plant } \\
\text { biomass } \\
\mathrm{g} / \mathrm{m}^{2}\end{array}$ & $\begin{array}{c}\text { Grain } \\
\text { mass, } \\
\mathrm{g} / \mathrm{m}^{2}\end{array}$ & $\begin{array}{c}\text { Economic } \\
\text { ratio, \% }\end{array}$ \\
\hline control & 1574 & 163.2 & 10.4 \\
\hline Rizoplan & 939 & 97.9 & 10.4 \\
\hline $\begin{array}{c}\text { chemical } \\
\text { preparation }\end{array}$ & 1431 & 181.6 & 12.7 \\
\hline $\begin{array}{c}\text { Streptomyces sp.: } \\
0.5 \mathrm{l} / \mathrm{ha}\end{array}$ & 871 & 130.5 & 15.0 \\
\hline $1.0 \mathrm{l} / \mathrm{ha}$ & 972 & 136.5 & 14.0 \\
\hline $1.5 \mathrm{l} / \mathrm{ha}$ & 1037 & 192.5 & 18.6 \\
\hline $2.0 \mathrm{l} / \mathrm{ha}$ & 1201 & 249.7 & 20.8 \\
\hline $\mathrm{LSD}_{0,5}$ & 269.58 & 33.65 & \\
\hline
\end{tabular}

The maximum grain yield in the experiment with $249.7 \mathrm{~g} / \mathrm{m}^{2}$ was obtained when applying Streptomyces sp. in the amount of 2.0 liters per ton of seeds. The excess in the grain yield over the control one and the one obtained when treating with a chemical preparation was 53 and $37.5 \%$, respectively. The additional yield was obtained due to an increase in the number of branches and inflorescences, as well as the number of full-fledged fruits.

\section{Conclusion}

The studies showed that in the arid conditions of 2018, the treatment of buckwheat seeds Batyr with Streptomyces sp reduced the field germination, increased the number of nodes and shoots, stimulated the biosynthesis of chlorophyll in the leaves during the period of active plant growth and development. In the leaves of the control option, treatment with Rizoplan and Streptomyces sp $(0.51 / \mathrm{t})$, increased the proportion of chlorophyll "b", whose value negatively correlated with productivity.

Based on the data on the regulatory properties of chlorophyll "b", it can be assumed that experimental variants with a reduced share of this fraction in the total amount accelerated the rate of formation of the plant reproductive system, thereby increasing the seed productivity of plants.

\section{Recommendations}

To increase the stability of buckwheat crops in regions with spring-summer drought during seed treatment, a bacterial preparation containing Streptomyces sp strains, activating the productive shoots, inflorescences, and fullfledged fruits can be used.

\section{Acknowledgments}

The study was conducted with the financial support provided by the Ministry Of Education And Science Of The Russian Federation. The subsidy agreement number is №14.610.21.0017. The unique identifier of the project is RFMEFI61017X0017.

\section{References}

1. M. Rosenblueth, E. Martinez-Romero, Molec. PlantMicrobe Interact., 19(8), 827-837 (2006)

2. R. Ryan, K. Germaine, A. Franks, D. Ryan, D. Dowling, FEMS Microbiol. Letters, 278(1), 1-9 (2008)

3. V. Chebotar, A. Scherbakov, E. Scherbakova, S. Maslennikova, A. Zaplatkin, N. Malfanova, Agricult. Biol., 5, 126-132 (2015)

4. V. Pronko, E. Narusheva, E. Yurchenko, Agricult. chem., 12, 18-26 (2009)

5. A. Karashaeva, Young sci., 6, 350-353 (2016)

6. J. Zhao, L. Zhong, L. Zou, C. Zhang, L. Peng, W. Xiao, G. Zhao, Cereal Res. Communicat., 43(2), 401-412 (2014)

7. S. Tummaramatti, L. Hedge, N. Vijaykumar, J. Chandra, Ecology, Environment and Conservation, 22, S55-S58 (2016)

8. L. Kadyrova, F. Kadyrova, Features of reproductive biology of Fagopyrum esculentum Moench in the conditions of the Tatarstan republic, Bull. of Kazan State Agrar. Univer., 4, 131-134 (2014)

9. Methodology of state variety testing of crops, 1, 269 (1985)

10. Yu. Fedulov, I. Trubnikova, A. Zagorulko, Proceedings of the Kuban Agrarian University named after I.T. Trubilin, 74, (2018)

11. E. Tyutereva, V. Dmitrieva, O. Wojciechowska, Agricult.1 Biol., 52(5), 843-855 (2017)

12. A. Fesenko, N. Fesenko, O. Romanova, Morphogenetic method of buckwheat selection (fagopyrum esculentum moench) (VIR, St. Petersburg, 2017)

13. K. Potapov, L. Kadyrova, F. Kadyrova, G. Galiullina, A. Khusnutdinova, I. Nikiforova, J. of Pharm. Res., 11. I.10, 1252-1256 (2017) 